https://doi.org/10.19195/2082-8322.12.7

Jakub Kalinowski

ORCID: 0000-0001-7918-6845

Uniwersytet Wrocławski

\title{
Obraz męskości w komunikacji skrajnie prawicowej organizacji Proud Boys
}

\section{Wstęp}

Postępujący kryzys męskości wskazywany przez badaczy, takich jak Michael Kimmel $^{1}$, Zbigniew Rykiel ${ }^{2}$, Zbyszko Melosik ${ }^{3}$, Philip Zimbardo ${ }^{4}$, Agnieszka Graff ${ }^{5}$ czy Emma Jane ${ }^{6}$, objawia się trudnościami mężczyzn w znalezieniu partnerek, nawiązywaniu kontaktów społecznych ${ }^{7}$ i problemami z seksualnością. Jego skutkiem jest między innymi nasilona polaryzacja społeczna, szczególnie widoczna wśród

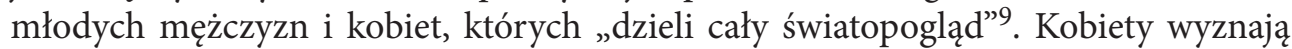
postępowe, liberalne wartości, co przekłada się zarówno na ich wybory polityczne, jak i życiowe, podczas gdy mężczyźni postępują dokładnie odwrotnie - głosują na

${ }^{1}$ M. Kimmel, Angry White Men. American Masculinity at the End of an Era, New York 2013.

2 Z. Rykiel, Klaunokracja 2.0 i bolesny koniec patriarchatu na semiperyferiach, „Przestrzeń Społeczna” 2016, nr 2, s. 7-32.

3 Z. Melosik, Kryzys męskości w kulturze współczesnej, Kraków 2006.

${ }^{4}$ P. Zimbardo, N. Duncan, The Demise of Guys. Why Boys Are Struggling and What Can We Do About It, New York 2012.

5 A. Graff, Manosfera, czyli bunt upokorzonych samców, „Czas Kultury” 2019, nr 1, s. 15-20.

6 E. Jane, Misogyny Online, Los Angeles 2016.

7 Z. Rykiel, op. cit., s. 8-9.

8 P. Zimbardo, N. Duncan, op. cit.

9 K. Pacewicz, Młodzi mężczyźni sa prawicowi i samotni, a młode kobiety liberalne $i$ w związkach [SONDAŻ], Wyborcza.pl, 27.04.2019, http://wyborcza.pl/magazyn/7,124059,24700696,mlodzi-wypisali-sie-z-politycznej-wojny-starszych-maja.html (dostęp: 6.09.2019). 
konserwatywną prawicę, a od swoich partnerek oczekują wyznawania tradycyjnych wartości ${ }^{10}$. Trend ten można zauważyć zarówno w Polsce, jak i w USA.

Kampania i sukces wyborczy Donalda Trumpa, a w szczególności jego kontrowersyjne stanowiska w kwestiach takich, jak migracja, feminizm czy islam, dopuściły do głosu rezydujące do tej pory $\mathrm{w}$ głębiach Internetu radykalnie prawicowe grupy polityczne. Największy rozgłos zyskał ruch Alternatywnej Prawicy (Alt-Right), który jednoczy w sobie między innymi ideologie rasistowskie, mizoginistyczne, antyimigranckie, homofobiczne i nacjonalistyczne. Treści antyfeministyczne szczególnie upodobała sobie, uważana za część Alt-Right, organizacja Proud Boys (PB). W jej postrzeganiu feminizm stanowi zagrożenie dla (białego) świata, a w szczególności tradycyjnego wzorca męskości uważanego przez nich za jedyny słuszny. Proud Boys w swoich materiałach promocyjnych przedstawiają się jednak w innym świetle. Postulują „maksymalną wolność” oraz otwarcie na mniejszości seksualne i rasowe, co wśród tradycyjnych skrajnie prawicowych ugrupowań było zazwyczaj niespotykane. Obraz świata proponowany przez Proud Boys może być bardzo atrakcyjny dla mężczyzn mających trudności z odnalezieniem się w zmieniającej się rzeczywistości.

$\mathrm{Z}$ uwagi na problemy współczesnych mężczyzn badanie obrazu męskości wynikającego z komunikacji grupy Proud Boys, które opisuje poniższy artykuł, wydaje się być ważne. Do badania wykorzystano metody charakterystyczne dla lingwistyki korpusowej. Sprawdziłem, jak budowany jest konstrukt męskości w komunikacji PB i czy odpowiada ona uznawanemu za tradycyjny patriarchalnemu modelowi. Szczegółowe pytania badawcze, na które starałem się odpowiedzieć, to: Na jakich tematach skupia się komunikacja PB? Co jest postrzegane jako męskie, a co jako niemęskie? Czy mężczyźni homoseksualni są uznawani przez PB za męskich? Czy ilość treści poświęcona masturbacji i pornografii odpowiada eksponowaniu tych tematów w materiałach promocyjnych $\mathrm{PB}$ ? Jakie cechy według $\mathrm{PB}$ powinien posiadać mężczyzna? Kogo PB podają jako przykład mężczyzny? Jaki jest cel życiowy mężczyzny? Jak PB przedstawiają rodzinę? Jaki powinien być stosunek mężczyzny do rodziny? Czy ojcostwo jest dla mężczyzny istotne? Jak PB przedstawiają kobiety? Jaki jest cel życiowy kobiety? Czym cechuje się kobieta? Postawiona przeze mnie hipoteza badawcza zakłada, że konstrukt męskości wynikający z komunikacji Proud Boys różni się od wzoru męskości typowego dla skrajnie prawicowych organizacji.

\section{Alt-Right i Proud Boys}

Na początek należy pokazać, dlaczego Alt-Right jest zjawiskiem wyjątkowym. Ruch został całkiem dokładnie zbadany z perspektywy politologicznej, między innymi

10 Ibidem. 
przez George'a Hawleya ${ }^{11}$, Thomasa J. Maina ${ }^{12}$, Matthew Lyonsa ${ }^{13}$ czy Piotra Śledzia $^{14}$. Zdecydowanie mniejsza liczba prac łączy Alt-Right z męskością. Należy tu wyróżnić wspomniany wcześniej wstępny raport z badań Agnieszki Graff ${ }^{15}$, pracę Annie Kelly ${ }^{16}$ i publikację Shannon Zimmerman, Luisy Ryan i Davida Duriesmitha ${ }^{17}$ oraz kompleksową książkę Angeli Nagle, opisującą internetowe grupy zaliczane do Alternatywnej Prawicy, a także ich związki z internetowymi subkulturami „skrzywdzonych mężczyzn”18. Wszyscy oni zgodnie twierdzą, że Alt-Right, w przeciwieństwie do jego skrajnie prawicowych protoplastów, nie może być opisany jako zorganizowany ruch. Nie posiada formalnych instytucji, a jednostki określające się jako część ruchu mają różne cele. Supremacja białej rasy jest dla nich kluczowym tematem, a ruch konserwatywny głównego nurtu zjednoczony pod szyldem Partii Republikańskiej - największym wrogiem ${ }^{19}$. Alt-Right uważa, że ludzie nie są równi, odrzuca zasady demokracji liberalnej, a za powód postępującego upadku Stanów Zjednoczonych uznaje zastąpienie dominacji białych równością rasową. Alternatywną Prawicę charakteryzuje także ,jadowita retoryka" ${ }^{20}$ oraz, na co zwracają uwagę zarówno Hawley, jak i Nagle, prowokacyjny, transgresywny humor, szczególnie atrakcyjny dla przesiadujących w Internecie młodych nihilistycznych mężczyzn ${ }^{21}$. Badacze akcentują także metapolityczny charakter Alt-Right. Oznacza to, że celem Alternatywnej Prawicy jest wpływ na kulturę i dyskurs medialny, a dopiero później osiąganie celów politycznych. Według nich „polityka jest zawsze zależna od kultury"22. Dzięki przemyślanym działaniom w Internecie, wycelowanym w dziennikarskie „filter bubbles”, mogą pochwalić się w tej kwestii wieloma sukcesami. Przez wysoką aktywność w bańkach dziennikarzy na Twitterze stworzyli mylne wrażenie na temat swojej liczebności, przez co przerażeni dziennikarze zaczęli o nich pisać.

11 G. Hawley, Making Sense of the Alt-Right, New York 2017; idem, The Alt-Right, New York 2019.

12 T.J. Main, The Rise of Alt-Right, Washington, D.C. 2018.

13 M. Lyons, Ctrl-Alt-Delete: The Origins and Ideology of the Alternative Right, Political Research Associates, 20.01.2017, https://www.politicalresearch.org/2017/01/20/ctrl-alt-delete-report-on-the-alternative-right (dostęp: 8.06.2019).

14 P. Śledź, Alt-Right - geneza i próba zdefiniowania zjawiska, [w:] Zmierzch demokracji liberalnej?, red. K.A. Wojtaszczyk, P. Stawarz, J. Wiśniewska-Grzelak, Warszawa 2018, s. 163-174.

15 A. Graff, op. cit.

16 A. Kelly, The alt-right: Reactionary rehabilitation for white masculinity, Eurozine, 15.09.2017, https://www.eurozine.com/the-alt-right-reactionary-rehabilitation-for-white-masculinity/ (dostęp: 8.06.2019).

17 S. Zimmermann, L. Ryan, D. Duriesmith, Recognizing the Violent Extremist Ideology of 'Incels', Women in International Security, 30.09.2018, https://www.wiisglobal.org/publication/recognizing-the-violent-extremist-ideology-of-incels/ (dostęp: 8.06.2019).

18 A. Nagle, Kill All Normies, Washington 2017.

19 G. Hawley, Making Sense of the Alt-Right..., s. 12.

20 T.J. Main, op. cit., s. 8.

21 A. Nagle, op. cit., s. 38-39; G. Hawley, Making Sense of the Alt-Right..., s. 71.

22 G. Hawley, Making Sense of the Alt-Right...,, s. 40-41. 
Nagłośnienie medialne wywołało sprzężenie zwrotne, które zaskutkowało jeszcze większą liczbą publikacji.

Według Angeli Nagle Proud Boys są „najbardziej zabawnym” spośród promęskich ruchów. Utrzymują skinheadowo-punkową estetykę i namawiają do abstynencji od masturbacji. Ich założyciel to Gavin McInnes, komik popularny w gronie Alt-Right, współzałożyciel i były redaktor „Vice” - internetowego magazynu przeznaczonego dla hipsterów, wśród których uznawany jest za ikonę. Proud Boys utrzymują system poziomów wtajemniczenia, które wymagają od nich między innymi zaprzestania masturbacji i wykonania tatuażu z nazwą organizacji. Pornografia i masturbacja są kluczowe dla filozofii PB, którzy przyjmują wobec niej konserwatywne stanowisko. Chcą jednocześnie najlepszych (dla nich) aspektów rewolucji seksualnej (łóżkowych sukcesów z dziewczynami wyglądającymi jak w filmach porno, gotowymi zrobić wszystko, czego zapragną), odrzucając towarzyszącą jej niepewność społeczeństwa, w którym kobiety posiadają wolność i mogą dokonywać własnych seksualnych wyborów. Pragną, aby kobiety były paniami domu (housewife) i całkowicie poświęcały się rodzinie ${ }^{23}$. Przez swoje działania, między innymi częste bójki z lewicowymi manifestantami, zdobyli reputację niezwykle agresywnej grupy ${ }^{24}$.

\section{Metodologia}

Do realizacji badania wykorzystano narzędzia i metody charakterystyczne dla lingwistyki korpusowej, zajmującej się analizą dużych zbiorów tekstowych, zwanych korpusami tekstowymi, z wykorzystaniem oprogramowania komputerowego ${ }^{25}$. Dzięki pracy na dużej liczbie tekstów możliwy jest bardziej zrównoważony dobór korpusu, a trafność uzyskiwanych wyników jest zwiększona. Listy frekwencyjne i słów kluczowych czy profile kolokacyjne zwiększają możliwość replikacji badań i ułatwiają przeprowadzenie badań porównawczych. Skupienie się na najczęściej powtarzających się konceptach czy słowach prowadzi do zmniejszenia stronniczości uzyskiwanych wyników. Oprogramowanie i techniki korpusowe sprzyjają ujawnianiu ukrytych tendencji obecnych $\mathrm{w}$ analizowanym materiale. To, co powtarzalne, staje się możliwe do zmierzenia dzięki wzorcom ilościowym ${ }^{26}$.

23 A. Nagle, op. cit., s. 95-96.

24 G. Hawley, The Alt-Right..., s. 196.

25 Lingwistyka korpusowa oraz jej narzędzia są omówione szerzej w publikacjach: A. Pawlikowska, Zastosowanie metod językoznawstwa korpusowego i lingwistyki kwantytatywnej w analizie dyskursu, „Oblicza Komunikacji” 5, 2012, s. 111-125; P. Baker, Using Corpora in Discourse Analysis, London-New York 2006; G. Kennedy, An Introduction to Corpus Linguistics, London-New York 1998; V. Kamasa, Techniki językoznawstwa korpusowego wykorzystywane w krytycznej analizie dyskursu. Przegląd, „Przegląd Socjologii Jakościowej” 10, 2014, nr 2, s. 100-117.

26 V. Kamasa, op. cit., s. 112. 
W badaniu posłużono się trzema narzędziami - listami frekwencyjnymi, kolokacjami oraz analizą KWIC. Lista frekwencyjna to lista wszystkich słów występujących w badanym korpusie, wraz z częstością ich wystąpień oraz udziałem procentowym danego wyrazu w całym korpusie ${ }^{27}$, pozwala identyfikować kluczowe leksemy wykorzystywane przez daną subkulturę ${ }^{28}$. Według Anny Wierzbickiej „Istnieje ścisła zależność pomiędzy życiem społeczeństwa a słownictwem języka, jakim to społeczeństwo mówi. Odnosi się to w tym samym stopniu do zewnętrznych przejawów życia, jak i do życia wewnętrznego, niedostrzegalnego gołym okiem"29. Słowa klucze są zatem słowami, które są dla danej subkultury „w jakiś szczególny sposób ważne i które mogą o niej wiele powiedzieć" 30 , pozwalają więc na lepsze zrozumienie określonych dyskursów subkulturowych.

Słowa uznane za kluczowe, jeżeli rzeczywiście są ważne dla komunikacji danej subkultury, powinny posiadać nie tylko dużą frekwencję, ale także być częścią kluczowych kolokacji, czyli słów często z sobą współwystępujących ${ }^{31}$. Jak twierdzi John Sinclair, kolokacje to dobry przewodnik w poszukiwaniu znaczenia słów, zwłaszcza gdy jest ono niejednoznaczne. Umożliwiają wskazanie najbardziej odpowiedniego sensu $^{32}$. Badając relacje między kolokacjami i konteksty, w których występują, można odkryć znaczenia charakterystyczne dla danego dyskursu subkulturowego. Słowa współwystępujące z danym leksemem mogą wpływać na jego końcowe znaczenie ${ }^{33}$.

Zarówno w przypadku słów kluczowych, jak i kolokacji istotne jest badanie kontekstów ich występowania, określane mianem analizy KWIC (Key Word in Context) lub analizy konkordancji. Za Paulem Bakerem należy rozumieć ją jako analizę wszystkich wystąpień danego wyrazu bądź kolokacji, wraz z kontekstami tych wystąpień ${ }^{34}$. Analiza konkordancji pozwala na identyfikację kontekstów, w których pojawia się badany przez nas leksem, a więc na poznanie jego głównego znaczenia lub funkcji w danym korpusie. Możliwe jest także wyszukanie wzorów, schematów i powtarzalności, które można następnie poddać kolejnym analizom ${ }^{35}$.

Pomimo wielu zalet metoda korpusowa bywa krytykowana. Brak jest przekonujących dowodów na to, że częstość występowania wyrazów w dyskursie jest najsilniejszym czynnikiem wpływającym na kształt społecznych i indywidualnych reprezentacji danego zjawiska. Jak twierdzi Victoria Kamasa, „Można przypuszczać, że

27 P. Baker, op. cit., s. 51; V. Kamasa, op. cit., s. 104-105; A. Pawlikowska, op. cit., s. 117.

28 A. Pawlikowska, op. cit., s. 117.

29 A. Wierzbicka, Słowa klucze. Różne języki - różne kultury, przeł. I. Duraj-Nowosielska, Warszawa 2007, s. 16.

30 Ibidem, s. 42.

31 V. Kamasa, op. cit., s. 107.

32 J. Sinclair, Reading Concordances. An Introduction, London 2003, s. 38.

33 M. Stubbs, Words and Phrases. Corpus Studies of Lexical Semantics, Oxford 2002, s. 30-32.

34 P. Baker, op. cit., s. 71.

35 J. Sinclair, op. cit., s. xvi-xvii. 
pewne wypowiedzi, czy to ze względu na ich autorów, czy też kształt samej wypowiedzi [na przykład szczególną wyrazistość — przyp. oryg.], mogą mieć silniejszy wpływ na konstrukcje dyskursywne obecne wśród odbiorców"36. Istnieje także ryzyko popełnienia błędu bądź nieścisłości na którymkolwiek etapie korzystania z technik korpusowych, które mogą prowadzić do trudnego do dostrzeżenia wypaczenia wyników. Analiza kolokacji niesie z sobą założenie, że częstość współwystępowania jest istotniejsza niż inne cechy połączeń między wyrazami. Założenia te mogą zostać podane w wątpliwość i wpłynąć na zakres i sposób interpretacji wyników. Analiza konkordancji skupia się na rekonstruowaniu funkcjonowania w badanym dyskursie słowa, a nie konceptu, który dane słowo reprezentuje, a który mogą wyrażać także inne słowa. Jak podkreśla Kamasa, większość problemów „może zostać rozwiązana przez przemyślaną i precyzyjną konstrukcję korpusów, a także uwzględnienie możliwych wątpliwości w opracowaniu i interpretacji wyników"37.

Przedmiotem badania był korpus zbudowany z tekstów pochodzących z publicznie dostępnego portalu „Proud Boy Magazine” (https://officialproudboys.com/) będącego oficjalnym medium grupy Proud Boys. Analizie został poddany zlematyzowany ${ }^{38}$ korpus tekstowy zawierający 250771 wyrazów, złożony ze wszystkich artykułów opublikowanych do 5 grudnia 2018 roku. Na początku wygenerowano listę frekwencyjną, która pozwoliła na identyfikację ważności danego słowa w korpusie. Wykluczone zostały elementy pełniące głównie funkcje gramatyczne, niewytwarzające znaczeń. $\mathrm{Na}$ jej podstawie skategoryzowano leksemy występujące w korpusie, w celu poznania ogólnej charakterystyki komunikacji grupy. Kolejnym krokiem była identyfikacja słów kluczowych dla konstruowania męskości. Zbadano konteksty wybranych słów, ich kolokacje, a następnie skategoryzowano leksemy według funkcji, jakie pełnią w tworzeniu obrazu męskości. Do analiz statystycznych i jakościowych wykorzystano oprogramowanie WordSmith Tools w wersji 5.0.0.334 oraz WordStat 8.

\section{Charakterystyka komunikacji Proud Boys}

Przed szczegółową analizą sposobów kreowania modelu męskości warto spojrzeć z szerszej perspektywy na kategorie, $w$ jakich komunikują PB. Tabela 1 przedstawia skategoryzowane na podstawie analizy kontekstów leksemy, występujące co najmniej trzydzieści razy w badanym korpusie.

\footnotetext{
36 V. Kamasa, op. cit., s. 112.

37 Ibidem, s. 113-114.

38 Lematyzacja jest procesem sprowadzania form fleksyjnych wyrazu do jego podstawowej formy.
} 
Tabela 1. Kategoryzacja leksemów występujących w korpusie

\begin{tabular}{|c|c|c|c|}
\hline Kategoria & Leksemy & $\begin{array}{c}\text { Fre- } \\
\text { kwen- } \\
\text { cja }\end{array}$ & Liczba \\
\hline Działanie & $\begin{array}{l}\text { event/wydarzenie, rally/zjazd, run/bieg, unite/zjednoczyć, wear/no- } \\
\text { sić, meet/spotkać się, create/tworzyć, change/zmiana, protest/pro- } \\
\text { testować, act/działać, support/wspierać, decide/decydować, leave/ } \\
\text { odchodzić, care/dbać, march/maszerować, action/akcja, move/po- } \\
\text { ruszać się, walk/chodzić, defend/bronić, push/pchać, vote/głosować, } \\
\text { attempt/próba, protester/protestujący, defense/obrona, pass/prze- } \\
\text { chodzić, protect/ochraniać, involve/wciągać, wait/czekać, imagine/ } \\
\text { wyobrażać sobie, notice/zauważać, explain/wyjaśniać, agree/zgadzać } \\
\text { się, choose/wybierać, join/dołączyć, stay/zostać, debate/dyskusja, } \\
\text { serve/służyć, disavow/wypierać się, argument/kłótnia, ignore/igno- } \\
\text { rować, refuse/odmawiać, discuss/dyskutować, pull/ciągnąć, realize/ } \\
\text { zrealizować, cut/ciąć, encourage/zachęcać, supporter/wspierający, } \\
\text { attend/uczęszczać, ban/zakazać, convince/przekonywać, decision/ } \\
\text { decyzja, disagree/nie zgadzać się, commit/popełniać, expose/eks- } \\
\text { ponować, choice/wybór, host/gospodarz, organize/organizować, } \\
\text { threaten/grozić, feed/karmić, accept/akceptować, argue/kłócić się, } \\
\text { avoid/unikać, celebrate/świętować, admit/przyznać, success/sukces, } \\
\text { apologize/przepraszać, assume/przypuszczać, represent/reprezento- } \\
\text { wać, seek/szukać }\end{array}$ & 4249 & 69 \\
\hline $\begin{array}{l}\text { Ruch/Proud } \\
\text { Boys }\end{array}$ & $\begin{array}{l}\text { boy/chłopiec, proud/dumny, group/grupa, McInnes, member/czło- } \\
\text { nek, Gavin, club/klub, order/rozkaz, brother/brat, Milo, ass/dupa, } \\
\text { fun/zabawa, joke/żart, degree/stopień, official/oficjalny, van, knight/ } \\
\text { rycerz, shirt/koszulka, drug/narkotyk, founder/założyciel, Chap- } \\
\text { man, fraternal/braterski, myth/mit, gang/gang, comedy/komedia, } \\
\text { chapter/sekcja (lokalny oddział), perry, laugh/śmiech, dangerous/ } \\
\text { niebezpieczny, funny/zabawny, Dyke, uhuru/wolność (w j. swahili), } \\
\text { Hunter }\end{array}$ & 4193 & 33 \\
\hline Ideologia & $\begin{array}{l}\text { left/lewica, Antifa, Alt/alternatywny, nazi/nazistowski, anti/anty, con- } \\
\text { servative/konserwatywny, liberal/liberalny, idea/idea, social/społecz- } \\
\text { ny, question/kwestia, side/strona, wrong/błędny, organization/organi- } \\
\text { zacja, issue/kwestia, leftist/lewak, wing/skrzydło, fascist/faszystowski, } \\
\text { movement/ruch, nationalist/nacjonalista, republican/republikański, } \\
\text { class/klasa, narrative/narracja, feminist/feminizm, extremist/ekstre- } \\
\text { mista, evil/zły, radical/radykalny, democrat/demokrata, pro/za (po- } \\
\text { pierając coś/kogoś), safe/bezpieczny, Hitler, marxist/marksistowski, } \\
\text { tie/więź, cuck/rogacz (mężczyzna, który ma niewierną żonę), socia- } \\
\text { list/socjalista, progressive/progresywny, communism/komunizm, } \\
\text { mask/maska, supremacist/suprematysta, equality/równość, belief/po- } \\
\text { gląd, agenda/agenda, color/kolor, nationalism/nacjonalizm, peaceful/ } \\
\text { pokojowy }\end{array}$ & 4064 & 44 \\
\hline
\end{tabular}




\begin{tabular}{|c|c|c|c|}
\hline $\begin{array}{l}\text { Przemoc/ } \\
\text { Walka }\end{array}$ & $\begin{array}{l}\text { fight/walczyć, attack/atakować, violence/przemoc, win/wygrać, kill/ } \\
\text { zabijać, shoot/strzelać, war/wojna, force/siła, gun/broń, throw/rzu- } \\
\text { cać, fire/ogień, lose/przegrać, death/śmierć, die/umierać, power/siła, } \\
\text { military/wojsko, rule/reguła, violent/brutalny, beat/bić, dead/mar- } \\
\text { twy, James, front/front, leader/lider, victim/ofiara, terrorist/terrory- } \\
\text { sta, pick/wybierać, threat/zagrożenie, punch/cios, security/bezpie- } \\
\text { czeństwo, weapon/broń, assault/napaść, murder/morderstwo, kick/ } \\
\text { kopać, destroy/niszczyć, target/cel, veteran/weteran, camp/obóz, pe- } \\
\text { ace/pokój, suck/ssać, terror/terror, warrior/wojownik, enemy/wróg, } \\
\text { soldier/żołnierz }\end{array}$ & 3366 & 44 \\
\hline Media & $\begin{array}{l}\text { media/media, video/wideo, speech/przemówienie, watch/oglądać, } \\
\text { news/wiadomości, speak/mówić, write/pisać, word/słowo, film/film, } \\
\text { movie/film, Facebook, read/czytać, article/artykuł, post/post, Twit- } \\
\text { ter, magazine/magazyn, Youtube, source/źródło, comment/komen- } \\
\text { tarz, journalist/dziennikarz, mainstream/główny nurt, interview/ } \\
\text { wywiad, response/odpowiedź, press/prasa, writer/pisarz, Google, } \\
\text { email/e-mail, CNN, mass/masowe, reporter/reporter }\end{array}$ & 3115 & 30 \\
\hline $\begin{array}{l}\text { Polityka/ } \\
\text { System }\end{array}$ & $\begin{array}{l}\text { Trump, law/prawo, political/polityczny, police/policja, president/ } \\
\text { prezydent, party/partia, report/raport, government/rząd, hold/trzy- } \\
\text { mać, society/społeczeństwo, control/kontrola, arrest/aresztować, } \\
\text { FBI, public/publiczny, SPLC, politics/politycy, bill/ustawa, election/ } \\
\text { elekcja, simply/prosto, statement/oświadczenie, Donald, policy/poli- } \\
\text { tyka, system/system, Clinton, cop/glina, Hillary, legal/prawny, DNC, } \\
\text { illegal/nielegalny, campaign/kampania, federal/federalny, wall/mur, } \\
\text { immigrant/imigrant, propaganda/propaganda }\end{array}$ & 2722 & 34 \\
\hline Czas & $\begin{array}{l}\text { time/czas, year/rok, day/dzień, week/tydzień, today/dzisiaj, history/ } \\
\text { historia, month/miesiąc, past/przeszłość, minute/minuta, ago/temu, } \\
\text { remember/pamiętać, modern/współczesny, hour/godzina, daily/ } \\
\text { dziennie, future/przyszłość, recently/niedawno, current/obecnie, } \\
\text { june/czerwiec, late/późno, moment/moment, october/październik, } \\
\text { present/teraźniejszość, recent/niedawny, forward/w przyszłość }\end{array}$ & 2539 & 24 \\
\hline Człowiek & $\begin{array}{l}\text { man/człowiek, life/życie, guy/facet, men/mężczyźni, live/żyć, friend/ } \\
\text { przyjaciel, person/osoba, age/wiek, eye/oko, kid/dzieciak, rest/resz- } \\
\text { ta, body/ciało, human/człowiek, individual/indywidualny, charac- } \\
\text { ter/charakter, young/młody, heart/serce, personal/osobisty, brain/ } \\
\text { mózg, mentally/mentalny }\end{array}$ & 2398 & 20 \\
\hline $\begin{array}{l}\text { Naród/ } \\
\text { Ameryka }\end{array}$ & $\begin{array}{l}\text { people/ludzie, American/amerykański, state/państwo, country/kraj, } \\
\text { America/Ameryka, USA/USA, national/narodowy, patriot/patrio- } \\
\text { ta, nation/naród, citizen/obywatel, Indian/Indianin, civil/cywilny, } \\
\text { amendment/poprawka, resident/rezydent, generation/generacja, } \\
\text { thanksgiving/święto dziękczynienia }\end{array}$ & 2354 & 16 \\
\hline Lokalizacja & $\begin{array}{l}\text { place/miejsce, York/Jork, city/miasto, Islamberg, community/spo- } \\
\text { łeczność, local/lokalna, street/ulica, Berkeley, north/północ, Char- } \\
\text { lottesville, land/ziemia, Washington/Waszyngton, town/miasto, } \\
\text { online/online, California/Kalifornia, area/obszar, internet/internet, } \\
\text { zone/strefa, space/przestrzeń, website/strona internetowa }\end{array}$ & 1283 & 20 \\
\hline
\end{tabular}




\begin{tabular}{|c|c|c|c|}
\hline Męskość & $\begin{array}{l}\text { drink/pić, drive/zapał, male/mężczyzna, strong/silny, bar/bar, beer/ } \\
\text { piwo, eat/jeść, suit/garnitur, workout/trening, training/trening, re- } \\
\text { spect/szacunek, food/jedzenie, practice/praktykować, sport/sport, } \\
\text { focus/skupienie, whiskey/whisky, strength/siła, fit/wysportowany, } \\
\text { Kaepernick, hook/hak, Rocky }\end{array}$ & 1031 & 21 \\
\hline Rasizm & $\begin{array}{l}\text { white/biały, black/czarny, racist/rasistowski, race/rasa, racism/ra- } \\
\text { sizm, racial/rasowy }\end{array}$ & 1017 & 6 \\
\hline Rodzina & $\begin{array}{l}\text { love/miłość, family/rodzina, home/dom, child/dziecko, house/dom, } \\
\text { mother/matka, father/ojciec, provide/zapewniać (byt), dad/tato, } \\
\text { mom/mama, parent/rodzic, wife/żona }\end{array}$ & 950 & 12 \\
\hline $\begin{array}{l}\text { Wiedza/ } \\
\text { Fakty }\end{array}$ & $\begin{array}{l}\text { fact/fakt, real/prawdziwy, true/prawdziwy, book/książka, truth/ } \\
\text { prawda, understand/rozumieć, answer/odpowiedź, learn/uczyć się, } \\
\text { evidence/dowód, experience/doświadczenie, teach/nauczać, theory/ } \\
\text { teoria }\end{array}$ & 939 & 12 \\
\hline Muzyka & $\begin{array}{l}\text { metal/metal, band/zespół (muzyczny), sound/dźwięk, record/nagry- } \\
\text { wać, album/album, punk/punk, music/muzyka, heavy/ciężki, song/ } \\
\text { piosenka, Sabbath }\end{array}$ & 835 & 10 \\
\hline Gospodarka & $\begin{array}{l}\text { work/praca, job/praca, money/pieniądze, pay/płacić, rich/bogaty, } \\
\text { business/biznes, sell/sprzedać, buy/kupić, market/rynek, career/ka- } \\
\text { riera }\end{array}$ & 788 & 10 \\
\hline Tożsamość & $\begin{array}{l}\text { culture/kultura, feel/czuć, western/zachodni, west/zachód, cultural/ } \\
\text { kulturowy, art/sztuka, diversity/różnorodność, european/europej- } \\
\text { ska, identity/tożsamość }\end{array}$ & 783 & 9 \\
\hline Świat & $\begin{array}{l}\text { world/świat, Russian/rosyjski, Russia/Rosja, Australia/Australia, } \\
\text { France/Francja, Germany/Niemcy, UK/Wielka Brytania }\end{array}$ & 662 & 7 \\
\hline Kobieta & woman/kobieta, girl/dziewczyna, date/randka, female/kobieta & 488 & 4 \\
\hline Religia & $\begin{array}{l}\text { muslim/muzułmański, god/bóg, islam/islam, islamic/islamski, chri- } \\
\text { stian/chrześcijański, sharia/szariat, religion/religia }\end{array}$ & 459 & 7 \\
\hline Seksualność & $\begin{array}{l}\text { gay/gej, gender/płeć, sex/seks, sexual/seksualny, couple/para, porn/ } \\
\text { pornografia, single/singiel }\end{array}$ & 396 & 7 \\
\hline Postawa & $\begin{array}{l}\text { hate/nienawiść, suicide/samobójstwo, anonymous/anonimowość, } \\
\text { feeling/uczucie }\end{array}$ & 365 & 4 \\
\hline Studia & $\begin{array}{l}\text { student/student, college/uniwersytet, university/uniwersytet, school/ } \\
\text { szkoła, study/studiować }\end{array}$ & 354 & 5 \\
\hline $\begin{array}{l}\text { Przestęp- } \\
\text { stwo/Spra- } \\
\text { wiedliwość }\end{array}$ & $\begin{array}{l}\text { crime/przestępstwo, rape/gwałt, court/sąd, justice/sprawiedliwość, } \\
\text { lawyer/prawnik, investigation/dochodzenie, steal/kraść }\end{array}$ & 305 & 7 \\
\hline Wolność & free/wolny, freedom/wolność & 273 & 2 \\
\hline Żydzi & Jew/Żyd, Jewish/żydowski & 108 & 2 \\
\hline
\end{tabular}

Źródło: opracowanie własne. 
Z tabeli wynika, że PB komunikują głównie na tematy związane z ideologią, własnym ruchem, mediami i polityką. Dominują leksemy związane z kategorią WALKA/PRZEMOC oraz DZIAŁANIE. Ich funkcją jest kreowanie narracji, według której obecnie trwa ciągły i nieustanny konflikt o przyszłość zachodniej kultury. Głównymi przeciwnikami w tej wojnie kulturowej są Lewica [Left] [416], Antifa [281] i Media $[283]^{39}$. Leksemy z kategorii DZIAŁANIE są stosowane w celu opisywania działań podejmowanych przez PB lub są nawoływaniem do podjęcia akcji bądź inicjatywy, włączenia się do walki. Często okazuje się ona przemocą lub przygotowaniem do niej, na przykład organizowanie wspólnych treningów bokserskich i ćwiczeń siłowych przygotowujących do bójek. Na podstawie analizy powyższej tabeli można wysnuć wniosek o nieścisłościach w komunikacji Proud Boys, którzy wielokrotnie podkreślali, że ich grupa jest bractwem, które chce tylko spotykać się w męskim gronie, żartować, pić piwo i rozmawiać o polityce.

Proud Boys są ruchem zdecydowanie politycznym, na co wskazuje wysoka pozycja kategorii MEDIA i POLITYKA/SYSTEM. Ich działania mają na celu zmianę sposobu myślenia, podjęcie działań, wywarcie wpływu na ludzi, organizacje i społeczeństwo. Część ich postulatów można uznać za rewolucyjne, na co wskazuje także kategoria IDEOLOGIA.

W korpusie wyraźnie zaznacza się także kategoria RUCH/PROUD BOYS, która znajduje poparcie w najczęściej pojawiających się leksemach, takich jak Proud [927], Boy [817], McInnes [277], Gavin [185], i dwóch frazach o największej frekwencji: Proud Boy [742] i Gavin McInnes [109], które wyraźnie dominują nad resztą. Sytuacja ta wskazuje na mocne skupienie komunikacji grupy na samej sobie oraz na swoim założycielu. Analiza KWIC wykazała, że Gavin McInnes jest przedstawiany w sposób niespójny, na przykład w artykule odpierającym gangsterskie zarzuty wobec PB możemy przeczytać:

„Proud Boys są gangiem”. Nasz założyciel (nie nasz lider, tylko facet, który to [Proud Boys - J.K.] zaczął) powiedział to w podkaście komediowym. [...] Bycie gangiem wymaga centralnego zarządzania i popełniania nielegalnych czynów. Ani jedno, ani drugie nie jest prawdą w naszym przypadku. McInnes nie ma wpływu na to, co robimy, a każda sekcja [lokalny oddział - J.K.] jest autonomiczna.

Natomiast $\mathrm{w}$ artykule dotyczącym organizowania treningów bokserskich czytamy: „W niespotykanym splocie zdarzeń rada starszych podjęła decyzję — Proud Boys muszą dołączyć do klubów bokserskich. Nasz lider, Gavin McInnes, zarządził to trzy godziny temu, a Proud Boys już zaczęli formułować plany na zaktywizowanie swoich grup".

39 Wszystkie cytaty i elementy wyróżnione kursywą w poniższym rozdziale pochodzą z badanego korpusu i były tłumaczone przez autora, chyba że zaznaczono inaczej. 
Tabela 2. Lista rangowa 50 słów o największej frekwencji w korpusie

\begin{tabular}{|c|c|c|c|c|c|c|c|c|}
\hline 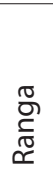 & 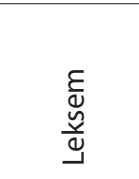 & 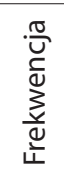 & 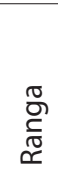 & $\begin{array}{l}\varepsilon \\
\stackrel{\Xi}{凶} \\
\stackrel{\mathscr{\Xi}}{\Xi}\end{array}$ & 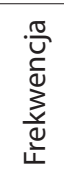 & 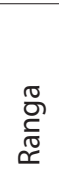 & 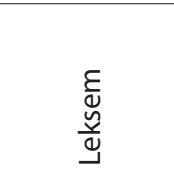 & 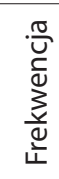 \\
\hline 1 & $\begin{array}{l}\text { proud/ } \\
\text { dumni }\end{array}$ & 927 & 18 & life/życie & 300 & 35 & love/miłość & 213 \\
\hline 2 & $\begin{array}{l}\text { people/ } \\
\text { ludzie }\end{array}$ & 905 & 19 & $\begin{array}{l}\text { woman/ } \\
\text { kobieta }\end{array}$ & 299 & 36 & video/wideo & 207 \\
\hline 3 & $\begin{array}{c}\text { boy/ } \\
\text { chłopiec }\end{array}$ & 817 & 20 & $\begin{array}{c}\text { American/ } \\
\text { amerykański }\end{array}$ & 292 & 37 & $\begin{array}{c}\text { nazi/ } \\
\text { nazistowski }\end{array}$ & 201 \\
\hline 4 & $\begin{array}{l}\text { make/ } \\
\text { tworzyć }\end{array}$ & 733 & 21 & guy/facet & 289 & 38 & start & 198 \\
\hline 5 & time/czas & 529 & 22 & media & 283 & 39 & $\begin{array}{l}\text { week/ } \\
\text { tydzień }\end{array}$ & 198 \\
\hline 6 & $\begin{array}{l}\text { group/ } \\
\text { grupa }\end{array}$ & 428 & 23 & Antifa & 281 & 40 & $\begin{array}{c}\text { member/ } \\
\text { członek }\end{array}$ & 197 \\
\hline 7 & $\begin{array}{c}\text { left/ } \\
\text { lewica }\end{array}$ & 416 & 24 & McInnes & 277 & 41 & free/wolny & 196 \\
\hline 8 & $\begin{array}{l}\text { white/ } \\
\text { biały }\end{array}$ & 377 & 25 & fuck/kurwa & 273 & 42 & $\begin{array}{c}\text { speech/ } \\
\text { mowa }\end{array}$ & 193 \\
\hline 9 & $\begin{array}{c}\text { man/ } \\
\text { człowiek }\end{array}$ & 345 & 26 & $\begin{array}{c}\text { men/ } \\
\text { mężczyźni }\end{array}$ & 272 & 43 & $\begin{array}{c}\text { attack/ } \\
\text { atakować }\end{array}$ & 192 \\
\hline 10 & $\begin{array}{l}\text { share/ } \\
\text { dzielić }\end{array}$ & 344 & 27 & work/praca & 267 & 44 & country/kraj & 190 \\
\hline 11 & $\begin{array}{l}\text { world/ } \\
\text { świat }\end{array}$ & 343 & 28 & $\begin{array}{c}\text { hate/ } \\
\text { nienawiść }\end{array}$ & 254 & 45 & $\begin{array}{l}\text { culture/ } \\
\text { kultura }\end{array}$ & 187 \\
\hline 12 & $\begin{array}{l}\text { thing/ } \\
\text { rzecz }\end{array}$ & 328 & 29 & $\begin{array}{c}\text { show/ } \\
\text { pokazywać }\end{array}$ & 254 & 46 & great/wielki & 186 \\
\hline 13 & year/rok & 327 & 30 & $\begin{array}{c}\text { alt/ } \\
\text { alternatywna }\end{array}$ & 250 & 47 & Gavin & 185 \\
\hline 14 & day/dzień & 311 & 31 & good/dobre & 247 & 48 & big/duży & 180 \\
\hline 15 & $\begin{array}{c}\text { call/ } \\
\text { dzwonić }\end{array}$ & 304 & 32 & $\begin{array}{c}\text { state/ } \\
\text { państwo }\end{array}$ & 246 & 49 & live/żyć & 180 \\
\hline 16 & Trump & 304 & 33 & $\begin{array}{c}\text { talk/ } \\
\text { rozmawiać }\end{array}$ & 243 & 50 & $\begin{array}{l}\text { America/ } \\
\text { Ameryka }\end{array}$ & 178 \\
\hline 17 & $\begin{array}{l}\text { black/ } \\
\text { czarny }\end{array}$ & 300 & 34 & $\begin{array}{c}\text { fight/ } \\
\text { walczyć }\end{array}$ & 239 & & & \\
\hline
\end{tabular}

Źródło: opracowanie własne. 
McInnes sytuowany jest także w roli wzoru. Możemy przeczytać o młodzieńczych bójkach Gavina, mających świadczyć o jego charakterze i męskości. Użycie wobec niego leksemów lider [leader] oraz frazy pokój $z$ nim [peace be upon him] ${ }^{40}$, a także sytuowanie $\mathrm{w}$ roli wzoru czyni $\mathrm{z}$ niego figurę o boskich konotacjach. To on spaja organizację i wyznacza jej ideologię. Struktura PB opiera się na działalności lokalnych oddziałów, które zachowują dużą autonomię w działaniach. Taka organizacja pomaga w manipulowaniu rzeczywistą liczbą członków (brak scentralizowanego spisu) oraz wzmacnia pozycję McInnesa, który nie ma konkurencji w strukturach PB.

Tabela 3. Lista rangowa 20 fraz o największej frekwencji

\begin{tabular}{|c|c|c|}
\hline Ranga & Fraza & Frekwencja \\
\hline 1 & Proud Boy & 742 \\
\hline 2 & Gavin McInnes & 109 \\
\hline 3 & free speech/wolność słowa & 94 \\
\hline 4 & United States/Stany Zjednoczone & 63 \\
\hline 5 & white nationalist/biały nacjonalista & 63 \\
\hline 6 & hate group/grupa szerząca nienawiść & 54 \\
\hline 7 & social media/media społecznościowe & 53 \\
\hline 8 & Proud Boy Magazine & 50 \\
\hline 9 & Black Sabbath & 41 \\
\hline 10 & Donald Trump & 41 \\
\hline 11 & white supremacist/biały suprematysta & 40 \\
\hline 12 & Alt Knight & 39 \\
\hline 13 & year ago/rok temu & 38 \\
\hline 14 & alt left/alternatywna lewica & 35 \\
\hline 15 & movie club/klub filmowy & 33 \\
\hline 16 & president Trump/prezydent Trump & 32 \\
\hline 17 & van Dyke & 31 \\
\hline 18 & fake news & 29 \\
\hline 19 & Proud Boy of the week/Proud Boy tygodnia & 29 \\
\hline 20 & left wing/lewica & 28 \\
\hline
\end{tabular}

Źródło: opracowanie własne.

40 „Pokój z nim” wyraża szacunek wobec proroka w islamie. Zwyczajowo umieszcza się to wyrażenie po wypowiedzeniu (bądź napisaniu) imienia proroka. 
Istotne dla PB są także kwestie związane z tematami NARÓD/AMERYKA oraz CZŁOWIEK. Są one nośnikami tożsamości, która jest ważnym elementem w obrazie męskości kreowanym przez komunikację Proud Boys. Ważnymi dla męskości (ale o mniejszym znaczeniu w kontekście całego korpusu) tematami są także IDEOLOGIA, GOSPODARKA, TOŻSAMOŚĆ. Kategorie MĘSKOŚĆ oraz istotna dla niej RODZINA znajdują się na dalszych, ale wciąż wysokich miejscach.

Leksemy i frazy dotyczące rasy oraz narodowości sytuują się wysoko pod względem frekwencji. Są one często używane w ramach obrony przed zarzutami, tak jak w przypadku fraz bialy nacjonalista [white nationalist] [63] i bialy suprematysta [white supremacist] [40]. Proud Boys nigdy nie opisują siebie takimi określeniami, ale często skupiają się na sytuacji osób rasy białej oraz podkreślają, że ich przeciwnicy polityczni kreują narrację wstydu, według której każdy biały człowiek powinien czuć wstyd z powodu bycia białym. PB przejawiają wobec tego swój wyraźny sprzeciw, co sugeruje ukryty rasizm badanej grupy.

\section{Męskość}

Przed przejściem do szczegółowej analizy sposobów konstruowania męskości przez PB warto przyjrzeć się szerzej, jakich kategorii używają w tym celu. Tabela 4 przedstawia podzielone na kategorie leksemy występujące w badanym korpusie co najmniej pięć razy. Odnoszą się one stricte do męskości, cech i atrybutów mężczyzny oraz rodziny i kobiet.

Tabela 4. Kategoryzacja leksemów uznanych za odnoszące się do męskości

\begin{tabular}{|c|c|c|c|}
\hline Kategoria & Leksemy & $\begin{array}{c}\text { Fre- } \\
\text { kwencja }\end{array}$ & Liczba \\
\hline Antymęskość & $\begin{array}{l}\text { left/lewica [416], Antifa [281], muslim/muzułmanie [162], li- } \\
\text { beral/liberalny [159], leftist/lewicowy [94], kid/dzieciak [79], } \\
\text { feminist/feminista(ka) [60], fake/podrobiony [54], democrat/ } \\
\text { demokrata (w USA) [51], rape/gwałt [49], cultural/kulturowy } \\
\text { [48], marxist/marksistowski [45], cuck/rogacz [40], socialist/ } \\
\text { socjalista [39], progressive/progresywny [38], communism/ko- } \\
\text { munizm [36], lazy/leniwy [26], vegan/weganin [22], faggot/pedal } \\
\text { [21], beta [14] }\end{array}$ & 1734 & 20 \\
\hline $\begin{array}{l}\text { Fizycznośćl } \\
\text { agresja }\end{array}$ & $\begin{array}{l}\text { fight/walczyć [239], attack/atakować [192], violence/prze- } \\
\text { moc [162], force/siła [114], throw/rzucić [110], military/mili- } \\
\text { tarny [81], violent/brutalny [71], beat/bić [62], punch/cios [52], } \\
\text { workout/trening [49], strength/siła [37], warrior/wojownik [31], } \\
\text { soldier/żołnierz [30], exercise/ćwiczenia fizyczne [19], knife/nóż } \\
\text { [17], fighter/wojownik [15], fist/pięść [14], boxing/boks [14] }\end{array}$ & 1309 & 18 \\
\hline
\end{tabular}




\begin{tabular}{|c|c|c|c|}
\hline Tożsamość & $\begin{array}{l}\text { American/amerykański [292], culture/kultura [187], America/ } \\
\text { Ameryka [178], western/zachodni [131], history/historia [111], } \\
\text { west/zachód [83], patriot/patriota [62], identity/tożsamość [37], } \\
\text { thanksgiving/święto dziękczynienia [31], chauvinist/szowinista } \\
\text { [23], tradition/tradycja [12], patriotism/patriotyzm [9] }\end{array}$ & 1156 & 12 \\
\hline Mężczyzna & $\begin{array}{l}\text { man/człowiek [343], guy/facet [289], men/mężczyźni [272], } \\
\text { male/męski [63], masculinity/męskość [11], manhood/męskość } \\
\text { [8], masculine/męski [7], alpha [5] }\end{array}$ & 998 & 8 \\
\hline Rodzina & $\begin{array}{l}\text { story/opowieść [161], family/rodzina [142], home/dom [93], } \\
\text { child/dziecko [92], house/dom [83], mother/matka [62], father/ } \\
\text { ojciec [57], dad/tata [47], parent/rodzic [38], mom/mama [38], } \\
\text { wife/żona [36], relationship/związek [33], son/syn [18], daddy/ } \\
\text { tatuś [16], husband/mąż [15], divorce/rozwód [15], marriage/ } \\
\text { małżeństwo [14], boyfriend/chłopak [14], daughter/córka [11] }\end{array}$ & 985 & 19 \\
\hline Charakter & $\begin{array}{l}\text { lead/przewodzić [101], drive/determinacja [87], lose/prze- } \\
\text { grać [87], defend/bronić [73], fun/zabawa [61], defense/obrona } \\
\text { [65], protect/chronić [64], character/charakter [55], training/tre- } \\
\text { ning [47], practice/praktyka [43], humor [26], risk/ryzyko [25], } \\
\text { role/rola [25], failure/porażka [19], responsibility/odpowiedzial- } \\
\text { ność [19], tough/twardy [15], dominate/dominować [15], confi- } \\
\text { dence/pewność [9], courage/odwaga [8], toughness/twardość [6] }\end{array}$ & 850 & 20 \\
\hline Atrybuty & $\begin{array}{l}\text { war/wojna [119], gun/broń [110], drink/pić [96], beer/piwo [53], } \\
\text { eat/jeść [52], weapon/broń [51], sport [42], whiskey [41], perry } \\
\text { [37], bourbon [27], meat/mięso [21], fred [20], hunting/myśli- } \\
\text { stwo [13], hunt/polować [12], shake/uścisk dłoni [9] }\end{array}$ & 703 & 15 \\
\hline Kobieta & $\begin{array}{l}\text { woman/kobieta [299], girl/dziewczyna [102], date/randka [49], } \\
\text { female/kobieta [38], lady/pani [26], girlfriend/dziewczyna [25], } \\
\text { chick/laska [24], beauty/piękno [14], housewife/gospodyni do- } \\
\text { mowa [9], venerate/czcić [9] }\end{array}$ & 594 & 10 \\
\hline Model & McInnes [275], Gavin [185], Milo [67], Peterson [27] & 554 & 4 \\
\hline Praca & $\begin{array}{l}\text { work/praca [267], job/praca [135], career/kariera [32], worker/ } \\
\text { pracownik [28] }\end{array}$ & 462 & 4 \\
\hline Seksualność & $\begin{array}{l}\text { gay/gej [100], gender/płeć [67], sex [65], sexual/seksualny [54], } \\
\text { porn/pornografia [35], wank/masturbować się [9], trans/trans- } \\
\text { seksualny [6], sexually/seksualnie [7], sexuality/seksualność [7], } \\
\text { sexy/seksowny [6], transsexual/transseksualny [6], homosexual/ } \\
\text { homoseksualny [5] }\end{array}$ & 378 & 12 \\
\hline Ideologia & $\begin{array}{l}\text { conservative/konserwatywny [163], republican/republikań- } \\
\text { ski [73], christian/chrześcijański [41], capitalism/kapitalizm [24], } \\
\text { church/kościół [19] }\end{array}$ & 321 & 5 \\
\hline
\end{tabular}

Źródło: opracowanie własne.

Dominującą kategorią jest ANTYMĘSKOŚĆ. Leksemy w niej zawarte odnoszą się do osób o światopoglądzie nieprzystającym do PB. Osoby należące do Antify [281], 
muzułmanie [muslim] [162], wyborcy partii demokratycznej [democrat] [51], socjaliści [socialist] [39] i feminiści [feminist] [60] nie mogą być w pełni mężczyznami, ponieważ ich czyny, determinowane przez wyznawane przez nich poglądy, nie są uznawane za męskie. Wobec tych mężczyzn używany jest termin beta. Typowy beta ma problemy ze znalezieniem partnerki, dla niego zarezerwowany jest friendzone, czyli nieseksualna relacja z kobietą. Betom brakuje pewności siebie, nie stać ich na wygłoszenie kontrowersyjnych opinii. Nazwanie mężczyzny betą jest największą obelgą. Grupy antymęskie widziane są jako zagrożenie dla wartości wyznawanych przez $\mathrm{PB}$ i to wobec nich stosowana jest opisana w poprzednim rozdziale retoryka walki. Aby zobrazować retorykę podejmowaną wobec wyżej wymienionych grup, posłużę się cytatem z zawartego w korpusie artykułu opisującego feministyczną pornografię:

Tak więc, jakie są kryteria „feministycznego porno”? Moim pierwszym przypuszczeniem była grupa tłustych, brzydkich lesb, robiących jakieś tłuste, brzydkie, lesbijskie gówno. (I nie byłem do końca w błędzie). Ale potrzeba było mężczyzny, aczkolwiek całkowitego bety, imieniem Russel O’Connor z Every-dayFeminism.com, żeby pomóc nam, normalnym facetom, ogarnąć ten przekręt, to znaczy pomysł.

Osoby utożsamiające się z feminizmem są przedstawiane w negatywnym świetle, a mężczyzna piszący dla feministycznego portalu tylko z tego powodu nazywany jest betą.

W komunikacji PB muzułmanie są kreowani jako ekstremiści, terroryści i ludzie nieszanujący kobiet. Ta ostatnia z cech — brak szacunku do kobiet — świadczy o ich niemęskości. Artykuły publikowane na stronie „Proud Boys Magazine” przedstawiają muzułmanów pochodzących na przykład z Indii czy Pakistanu i cechy z nimi utożsamiane przenoszą na muzułmanów będących mieszkańcami bądź obywatelami Stanów Zjednoczonych: „kobiety są wciąż postrzegane jako sprzęt rolniczy i maszyny do rodzenia dzieci, w społeczeństwach zdominowanych przez muzułmanów".

Najważniejszą kwestią jest to, że muzułmanie głośno oponuja przeciw jakimkolwiek możliwym zmianom $w$ sposobie życia kobiety. Wartości Koranu według jednego $\mathrm{z}$ artykułów zawartych w korpusie to: „Przyzwolenie na przemoc, przyzwolenie na kłamstwa, przyzwolenie na pedofilię, homofobia, przestępstwo myślowe, ścinanie głów, okaleczanie genitaliów, posłuszeństwo, bomby, ataki ciężarówkami, napady nożowników, strzelaniny, gwałty i kazirodztwo".

Celem tej retoryki jest przeciwstawienie obcych muzulmańskich gangów gwałcacych zachodnie kobiety amerykańskim mężczyznom, którzy je szanują, a nawet czcza [venerate], czym konstruują to, jaki mężczyzna powinien być.

Podobnie jak w ogólnych kategoriach, kwestia AGRESJI/FIZYCZNOŚCI znajduje się na wysokiej pozycji, co nie powinno dziwić, biorąc pod uwagę agresję, z której Proud Boys słyną. Leksemy z powyższej kategorii dobrze współpracują z leksemami występującymi w temacie CHARAKTER. Walka, ćwiczenia fizyczne, siła czy bójki są poparte silną psychiką, determinacją i długotrwałą praktyką, mającą na celu wyprodukowanie mężczyzny odpornego psychicznie i silnego fizycznie. 
Kategoria TOŻSAMOŚĆ współgra z sąsiadującą z nią kategorią CZłOWIEK. Leksemy do nich należące często są kolokacjami i występują w podobnych kontekstach. Leksemy człowiek [man] [343] i mężczyźni [men] [272], z racji swojego znaczenia, są trudne do skategoryzowania i analizy. W języku angielskim są one używane zarówno do opisu człowieka (lub ludzi), jak i mężczyzny (lub mężczyzn). W kontekście komunikacji Proud Boys zazwyczaj oznaczają one mężczyznę (lub mężczyzn), a jeżeli leksem man jest używany w znaczeniu człowiek, to rzadko kiedy odnosi się on również do kobiet. Jeżeli zsumujemy obydwa leksemy, uzyskamy frekwencję wynoszącą [615]. Człowiek (w domyśle mężczyzna) jest więc dominującym wyrazem wśród słów kluczowych dla obrazu męskości. Tym samym komunikacja PB w znaczącym stopniu dotyczy tego, jaki dany człowiek jest lub jaki ogólnie być powinien.

Jak zostanie pokazane w dalszej części rozdziału, RODZINA, pomimo braku wyraźnej dominacji nad resztą kategorii, jest niezwykle istotna dla Proud Boys. Analiza jakościowa wykazała, że w życiu mężczyzny rodzina jest najważniejszą wartością. Bycie mężczyzną w ostateczności prowadzi do prokreacji, założenia rodziny oraz dbania o nią.

Kategoria ATRYBUTY zbiera w sobie leksemy, które są pewnymi symbolami, czynnościami, zjawiskami lub przedmiotami, które każdy mężczyzna powinien wykonywać (w odpowiedni sposób), posiadać lub szanować (mieć pozytywny stosunek do nich). Powyższa kategoria zawiera leksemy takie jak wojna [war] [119] — traktowana jako typowo męska rzecz, która nie powinna dotyczyć kobiet. Podobnie jest z bronia [gun] [110], piwem [beer] [53], burbonem [bourbon] [27] czy uściskiem dłoni [shake] [9]. Są to wyłącznie męskie rzeczy.

Kategorie PRACA i IDEOLOGIA stanowią dopełnienie konstruktu męskości, a osoby, do których odnoszą się leksemy zawarte w temacie MODEL, są uznawane za postacie godne naśladowania. Pomimo niskiego miejsca kategorii leksemy praca [work] [267] i [job] [135] zajmują wysokie miejsce wśród najczęściej pojawiających się leksemów, co świadczy o ich istotności w komunikacji Proud Boys.

Rola kobiety w obrazie świata Proud Boys jest w zasadzie sprowadzona do dwóch aspektów - rodziny, czyli prokreacji i zajmowania się gospodarstwem domowym, oraz seksu. Kategorie KOBIETA i SEKSUALNOŚĆ często z siebie wynikają. Podobnie jak z kategorią PRACA, leksemy kobieta [woman] i dziewczyna [girl] zajmują wysokie, trzecie oraz dwudzieste ósme miejsce wśród słów kluczowych, są więc ważne dla komunikacji Proud Boys.

\section{Mężczyzna}

Proud Boys, jako organizacja biorąca czynny udział w wojnie kulturowej, zwraca szczególną uwagę na to, jak kształtowany jest człowiek, jakie wyznaje wartości i jakie zachowania uznaje za słuszne. Leksemy człowiek [man] i mężczyźni [men] pojawiają się łącznie 615 razy w badanym korpusie. 
Tabela 5. Lista 20 najczęstszych kolokacji leksemów men i man

\begin{tabular}{|c|c|c|}
\hline Ranga & Kolokacja $(n-5 n+5)$ & Frekwencja \\
\hline 1 & woman/kobieta & 40 \\
\hline 2 & white/biały & 31 \\
\hline 3 & boy/chłopiec & 30 \\
\hline 4 & proud/dumny & 29 \\
\hline 5 & club/klub & 27 \\
\hline 6 & movie/film & 20 \\
\hline 7 & American/amerykański & 13 \\
\hline 8 & watch/oglądać & 12 \\
\hline 9 & time/czas & 12 \\
\hline 10 & films/filmy & 11 \\
\hline 11 & western/zachodni & 10 \\
\hline 13 & love/miłość & 10 \\
\hline 14 & based/nikczemny & 8 \\
\hline 16 & culture/kultura & 8 \\
\hline 17 & gay/gej & 8 \\
\hline 18 & sex/seks & 8 \\
\hline 19 & rights/prawa & 8 \\
\hline 20 & organization/organizacja & 8 \\
\hline
\end{tabular}

Źródło: opracowanie własne.

Leksemy odnoszące się do człowieka tworzą wiele kolokacji. Najczęściej występującą kolokacją jest kobieta [woman] [40]. Kobieta odgrywa ważną rolę w życiu mężczyzny - to o nią walczą mężczyźni, to dla niej ubierają garnitury. Kobiety są kochane przez mężczyzn, traktuje się je $z$ szacunkiem. Zachodni mężczyzna powinien znaleźć „amerykańską konserwatywną kobietę z umiarkowanie chrześcijańskimi poglądami, nie radykalistkę, ale taką z dobrymi zasadami i budującymi wartościami, które pomogą w tworzeniu uczciwej i dumnej zachodniej rodziny". Rola kobiety w życiu mężczyzny jest jasno określona - ma ona wychowywać dzieci i zajmować się domem.

Kolejną często występującą kolokacją jest biały [white] [31]. Określenie white man jest używane w kontekście walki z kulturq wstydu. Facet nie powinien czuć wstydu $z$ bycia heteroseksualnym białym mężczyzna. Biały człowiek jest także stosowany w historycznych kontekstach, na przykład podboju Ameryki przez Krzysztofa Kolumba i walki z Indianami, a także przy opisywaniu sytuacji konfliktowych, w których biorą udział ludzie ras innych niż biała. Przy pomocy powyższej frazy kreowany jest obraz 
skrzywdzonego, złego (w opinii innych) białego człowieka, którego jedyną winą jest to, że jest biały (i jest mężczyzną).

Według Proud Boys to mężczyźni stworzyli nowoczesny świat. Kiedy kobiety stały z tyłu i pielęgnowały rodzinę, mężczyźni byli kręgosłupem kraju (Ameryki). PB twierdzą, że historia uczy o tym, że silniejszy pokonuje słabszego, a mężczyźni konkuruja o zasoby $i$ kobiety. Dawniej mężczyźni nie rozmawiali o swoich uczuciach i zajmowali się tylko ważnymi sprawami, w przeciwieństwie do dzisiejszych czasów, kiedy mają depresję, a czas spędzają na graniu w gry wideo, spaniu i masturbacji. W dodatku nazywają się feministami, kompletnie nie wiedząc, że są ofiarami zniewieściałej, słabej, niemoralnej kultury feministycznej porażki. Są udawanymi mężczyznami.

Prawdziwi mężczyźni są zbudowani do walki. Celem Proud Boys jest propagowanie tradycyjnych wzorów męskości, to, żeby znów być silnymi mężczyznami. Siła jest potrzebna do bezpiecznego życia. Powinna być praktyczna, mężczyzna powinien móc ją wykorzystać w codziennym życiu. Buduje się ją przez regularny trening siłowy, polegający na podnoszeniu ciężkich rzeczy. Modelem na tym polu są komandosi specnazu. Żeby móc ją rozwijać, mężczyzna powinien odpowiednio się odżywiać, to znaczy jeść dużo mięsa, a najlepiej steków. Mięso jest atrybutem typowo męskim. Proud Boys uważają, że siła fizyczna jest bezpośrednio skorelowana $z$ możliwościa ochrony swojej rodziny i zdobywania dla niej środków do życia. Silny mężczyzna jest także pewny siebie i odważny. Siła jest bezpośrednio powiązana z walką. Wyprowadzenie ciosu jest podstawowa umiejętnościa na drodze do męskości. Oprócz walki fizycznej mężczyzna powinien podejmować także walkę polityczną. Według PB czas na akcję jest teraz - młodzi konserwatyści powinni zabrać głos i walczyć o duszę Ameryki. Mężczyzna nie może oddać niczego bez walki.

W wizji Proud Boys mężczyzna nie powinien dbać o swój komfort. Powinien zachowywać się jak dorosły. W jego życiu nie liczy się jednak tylko fizyczność:

Nie możemy zapomnieć o aspekcie mentalnym. Drogie panie, amerykański mężczyzna nie jest tylko nieruchomą górą mięśni. Rycerskość nie zniknęła, a głód intelektualny i chęć spędzenia uczciwego dnia w pracy jest siłą, która pcha go na szczyty łańcucha pokarmowego społeczeństwa.

Dzięki determinacji i ciężkiej pracy mężczyzna dąży do sukcesu, bez względu na poniesione porażki. Sama praca jest dużą wartością dla mężczyzny, uczy życia, dostarcza ciekawych doświadczeń, które zawsze się przydadzą. Proud Boys wartościują pracę fizyczną. Utożsamiają się z „niebieskimi kołnierzykami” i wierzą, że ciężką pracą można osiągnąć sukces. Istotna w życiu jest etyka pracy, która jest elementem kształtującym charakter.

Codzienne zmagania tworzą mężczyznę. Charakter jest kształtowany między innymi przez regularne ćwiczenia fizyczne. To one budują wytrzymałość psychiczną, wyrugowują lenistwo i pomagają w codziennym utrzymywaniu swoich zasad. Najlepszym sportem dla mężczyzny (nie licząc treningu siłowego) jest boks: „Polecam każdemu pełnosprawnemu mężczyźnie znaleźć lokalny klub bokserski. Nie tylko jest 
to diabelnie ciężki trening, ale też jedna z najlepszych rzeczy, jaką możesz zrobić, żeby być lepszym i zbudować pewność siebie”.

Oprócz aspektu mentalnego ćwiczenia są zdrowe dla ciała i polepszają wygląd, który umożliwia znalezienie partnerek seksualnych. W kwestii wyglądu mężczyzna powinien mieć krótkie włosy, może mieć wąsy lub brodę. Ubiór też jest prosty. Garnitury sa tym, co nosimy jako mężczyźni.

Mężczyźni mają wartości, za które mogliby umrzeć. Tak jak ich przodkowie „wiedzieli, że istnieją rzeczy, za które warto umrzeć. Rodzina, kraj, wolność, honor, ideały, duma i pasja grały rolę w stwarzaniu kogoś, kim byli”. Dawniej nie bano się pojedynków i to był podstawowy sposób rozwiązywania problemów. Dzisiaj są one nielegalne, ale czasami mężczyźni musza się z soba pobić. To naturalne i dobre dla duszy.

Wolny czas mężczyźni spędzają na oglądaniu lub uprawianiu sportu, piciu alkoholu, najlepiej piwa budweiser i whiskey, ze znajomymi. Dyskutują przy tym o polityce, kobietach i bawią się z dziewczynami. Sport jest męski, ponieważ przemawia do naturalnego instynktu faceta: „Kto, do cholery, nie lubi sportu? Sport przemawia do naszych najbardziej zwierzęcych instynktów - chęci uderzania rzeczy i udowadniania, że jest się lepszym niż inni ludzie”.

Wyjście z chłopakami [a night out with boys] jest ważne. Piwo jest nieodłącznym elementem tych spotkań i w dyskursie PB funkcjonuje jako wieloznaczeniowy symbol. Przy piwie faceci mogą się pojednać po odbytej bójce, zimne piwo jest nagrodą za ciężki dzień pracy, buduje ono także braterskie więzi. Pijąc piwo, mężczyzna staje się bardziej męski. Piwo dobrze łączy się z grillem. Żeby było męskie, musi być proste; picie piwa craftowego jest jak seks $z$ transwestytą. Powinno być pite szybko i w dużych ilościach. Proud Boys pija piwa duszkiem, aż zaczynaja wymiotować. Stosunek PB do piwa dobrze podsumowuje cytat pojawiający się w artykule odnoszącym się do Ala Bundy'ego - piwo to moje paliwo [beer gives you gas].

Proud Boys mocno eksponują swój stosunek do seksualności. Przede wszystkim uważają, że mężczyzna nie powinien się masturbować częściej niż raz w miesiącu. Oglądanie pornografii i masturbacja to cechy charakterystyczne dla nastolatków. Sprawiają one, że życie jest gorsze. Ma to zachęcać do poszukiwania partnerek seksualnych, zwiększać pewność siebie i charyzmę. Kwestia płci także jest dla nich prosta. Istnieją tylko dwie biologiczne płcie. Jesteś albo mężczyzną, albo kobietą. Proud Boys mają dwojaki stosunek do homoseksualizmu. W wielu oświadczeniach mających na celu wybielenie ich wizerunku twierdzą, że ich poglądy są liberalne, nie zwracają uwagi na orientację seksualną, a w ich szeregach znajdują się homoseksualiści i transseksualiści. Kiedy indziej używają leksemu gej [gay] jako inwektywy i utożsamiają gejów z przeciwieństwem mężczyzny, tuż obok Antify, feministów i lewicy. Równość małżeństw dwu- i jednopłciowych jest dla nich niedopuszczalna, ponieważ w wyniku jej legalizacji małżeństwo traci znaczenie. Takie podejście określają mianem prorodzinności [pro-family].

Dużą kwestię w wizji Proud Boys odgrywa koncept zachodu [west], zachodnich wartości [western values], zachodniego człowieka [western man]. Członkowie gru- 
py sami siebie określają jako zachodnich szowinistów [western chauvinist]. Wartości utożsamiane $\mathrm{z}$ zachodem to bóg, patriotyzm, wolność, a także matżeństwo, rodzina i $d z i e c i$ - „Powinienem mieć już jedno dziecko i czekać na kolejne. Mógłbym być już żonaty i wnosić wkład do naszych zachodnich wartości”.

\section{Rodzina}

Posiadanie rodziny niesie za sobą wiele obowiązków. Mężczyzna powinien wykorzystywać wszystkie swoje cechy - determinację, pewność siebie, etykę pracy, siłę fizyczną i psychiczną itd. - do ochrony rodziny, domu, dzieci i kobiet, do zarabiania pieniędzy, aby ją utrzymać. Rodzina jest największą wartością dla mężczyzny, to jej powinien podporządkować swoje życie.

Tabela 6. Lista kolokacji leksemów family

\begin{tabular}{|c|c|c|}
\hline Ranga & Kolokacje $(\mathrm{n}-5 \mathrm{n}+5)$ & Frekwencja \\
\hline 1 & love/miłość & 6 \\
\hline 2 & friends/przyjaciele & 5 \\
\hline 3 & home/dom & 5 \\
\hline 4 & proud/dumny & 4 \\
\hline 5 & black/czarny & 4 \\
\hline 6 & man/mężczyzna & 4 \\
\hline 7 & protect/chronić & 4 \\
\hline 8 & country/kraj & 4 \\
\hline 9 & girlfriend/dziewczyna & 4 \\
\hline 10 & traditional/tradycyjna & 3 \\
\hline 11 & people/ludzie & 3 \\
\hline 12 & rich/bogaty & 3 \\
\hline 13 & left/lewica & 3 \\
\hline 14 & boys/chłopcy & 3 \\
\hline 15 & day/dzień & 3 \\
\hline 16 & make/robić & 3 \\
\hline
\end{tabular}

Źródło: opracowanie własne.

Pomimo swojej istotności leksem rodzina [family] ze 142 wystąpieniami i dwudziestym miejscem na liście słów kluczowych odnoszących się do męskości nie tworzy wielu kolokacji, które w dodatku pojawiają się nie częściej niż sześć razy. 
Leksem miłość [love] odnosi się do kochania swojej rodziny. Jej członkowie powinni się wzajemnie kochać i wspierać. W rodzinie człowiek powinien zawsze znaleźć oparcie. Podobną funkcję pełnią przyjaciele [friends]. Z ich pomocą człowiek nigdy nie zostanie sam ze swoimi problemami. Według PB istotne są bliskie więzi między ludźmi, rodzina i bliscy mają priorytet przed wszystkimi. Relacje z nią świadczą o człowieku. Tradycyjna rodzina służy przede wszystkim społeczeństwu. Przyszłość jest budowana przez rodziny, a Proud Boys sa tymi, którzy je tworza. Jej funkcją jest prokreacja, a dzieci są jej spuścizną — „Mam nowo narodzone dziecko, siostrzenicę imieniem Summer, urodzoną 16 listopada. Jest zdrowa, zachwycająca i jest spuścizną mojej rodziny".

Rodzina jest także utożsamiana ze spokojem, obecność rodzin na wydarzeniach politycznych ma świadczyć o ich przyjaznym i pokojowym przebiegu.

Leksemy dom [home] i chronić [protect] często z sobą współwystępują. Ochrona domu i rodziny jest obowiązkiem mężczyzny, w tym celu powinien on być zdolny nawet do zabicia innej osoby:

musimy chcieć nie tylko zginąć za naszych ukochanych, ale też walczyć i zabić, jeżeli jest to konieczne do zapewnienia im bezpieczeństwa. Niezrobienie tego jest tchórzostwem, a mężczyzna, który nie użyje pięści, żeby obronić swoją rodzinę, nie jest mężczyzną.

W tym celu przydaje się trening boksu, który buduje charakter i pewność siebie. Dla rodziny ważne jest to, żeby mężczyzna spędzał z nią czas, to jest przebywał $w$ domu. Powinien on stawiać ją zawsze na pierwszym miejscu:

To jest powracający wątek w życiu Ala: jego gotowość do odstawienia swojej przyjemności dla dobra rodziny. Nadarzały się okazje do bycia niewiernym, ale on nigdy nie zbłądził. Rozumiał znaczenie rodziny nuklearnej, tak jak rozumieją ją Proud Boys.

W rodzinie to mężczyzna jest odpowiedzialny za podejmowanie decyzji, jest jej głową. Zarabia pieniądze i stanowi przykład dla swoich dzieci. Obowiązuje tradycyjny podział ról społecznych, a kobieta powinna zajmować się domem i dziećmi, być gospodynią.

Rodzina jest jedną z amerykańskich lub zachodnich wartości. Prawdziwy Amerykanin powinien ją szanować: „W każdym Amerykaninie, który chce odnosić sukcesy, jest coś. Chcemy kochać nasz kraj, mieć rodziny i nie chcemy, żeby ktoś mówił nam, co mamy robić”. Znajduje się ona w sercu amerykańskiej kultury, jest jej centralnq wartością. Mężczyzna powinien znać historię swojej rodziny w takim samym stopniu, w jakim zna historię swojego kraju. Wszystkie postacie (realne i fikcyjne) przedstawiane jako wzory męskości posiadają rodziny.

Największym szczęściem jest posiadanie dziecka, najlepiej syna:

Sam mam syna i naprawdę jest on największym darem, jaki otrzymałem. [...] Codziennie jest dla mnie powodem do dumy. Ale wiem, że jest moim małym chłopcem, i muszę odpowiednio nim pokierować, ponieważ jedną z moich najwyższych powinności jest pokazanie mu, jak mężczyzna żyje w świecie. 
Ojciec jest kochający, madry, przystojny i ciężko pracujacy. Jego rolą jest bycie modelem, przewodnikiem. Uczy zasad i przekazuje wartości. Gdy go brakuje, dziecko może zostać lewakiem. Bycie ojcem to najwyższa forma spełnienia dla faceta, esencja męskości.

Posiadanie rodziny (bądź chęć jej posiadania) są wyznacznikiem męskości: „Nauczyliśmy się tego, że kiedy dostajemy solidny uścisk dłoni, zazwyczaj pochodzi on od reporterów posiadających rodziny".

Żeby chłopak stał się mężczyzną, musi odłożyć na bok spanie do późna, gry wideo i masturbację, co ma pomóc mu w znalezieniu partnerki i założeniu rodziny. W trakcie swoich spotkań $\mathrm{PB}$, oprócz picia piwa, zachęcają się nawzajem do rozpoczynania związków, oświadczyn, w celu założenia rodziny: „W rzeczywistości duża część naszych spotkań polega na zachęcaniu do wchodzenia w związki, zaręczania się ze swoimi dziewczynami i ostatecznie do założenia rodziny".

Proud Boys uważają, że marksizm kulturowy wraz z lewicą są największym zagrożeniem dla rodziny. Odciągają społeczeństwo od chrześcijańskich wartości, przez co ludzie tracą sens życia, promują rozwody, powodują, że ludzie rodzą mniej dzieci. Mniejsza reprodukcja jest popełnieniem kulturowego samobójstwa.

\section{Kobieta}

Jeden z głównych postulatów Proud Boys odnosi się do roli kobiet w życiu rodzinnym. PB czcza gospodynie domowe [venerate the housewife], co jest jasnym określeniem pozycji kobiet $\mathrm{w}$ społeczeństwie. Ograniczenie kompetencji kobiet tylko do obowiązków domowych zamyka im drogę do wywierania wpływu na to, jak wygląda świat. Kobiety w historii pisanej przez Proud Boys zawsze trzymały się z tyłu. Tworzenie świata należało do mężczyzn, podczas gdy kobiety zajmowały się rodziną. Jest to wzorzec, który PB chcieliby przywrócić w dzisiejszych czasach: „To mężczyźni opodatkowali swoje ciała i stawiali się w potrzebie, podczas gdy kobiety trzymały się $\mathrm{z}$ tyłu i czule pielęgnowały rodzinę".

Według nich „szklany sufit” nie istnieje, kobiety miały i mają możliwość zostania prezydentem kraju. To, że żadna kobieta jeszcze nie objęła najwyższej funkcji w państwie, nic nie znaczy.

Kolokacje leksemu kobieta często odnoszą się do organizacji PB. Leksemy mężczyźni i anty są wykorzystywane w celu odparcia zarzutów o antykobiecość PB. Lewica i muzulmanie to zagrożenie dla pozycji kobiety w społeczeństwie. PB uważają, że lewicowcy nie szanują kobiet, które wybierają opiekę nad domem zamiast kariery, a muzułmanie traktują kobiety jako nie-ludzi.

W swojej komunikacji PB wyraźnie odgraniczają cechy kobiece od męskich:

Proud Boys nie doceniają tylko kobiecego piękna, kobiety są doskonałe w wielu kwestiach, w których mężczyźni nie są. Cierpliwość, pielęgnowanie, przykładanie wagi do detali, wychowywanie dzieci 
i prowadzenie domu nie czyni z kobiet obywateli drugiej kategorii, tylko perfekcyjną „drugą połowę” balansującą klasyczną męskość.

Tabela 7. Lista kolokacji leksemu woman

\begin{tabular}{|c|c|c|}
\hline Ranga & Kolokacje $(\mathrm{n}-5 \mathrm{n}+5)$ & Frekwencja \\
\hline 1 & men/mężczyźni & 37 \\
\hline 2 & anti/anty & 13 \\
\hline 3 & left/lewica & 8 \\
\hline 4 & black/czarny & 8 \\
\hline 5 & muslim/muzułmanie & 8 \\
\hline 6 & make/tworzyć & 7 \\
\hline 7 & love/miłość & 7 \\
\hline 8 & raping/gwałcić & 6 \\
\hline 9 & trans/transpłciowy & 6 \\
\hline 10 & pro/za (popierać coś/kogoś) & 6 \\
\hline 11 & conservative/konserwatywny & 5 \\
\hline 12 & rights/prawa & 5 \\
\hline 13 & march/marzec & 5 \\
\hline 14 & Jewish/żydowskie & 5 \\
\hline 15 & restroom/toaleta & 5 \\
\hline 16 & great/wielki & 5 \\
\hline
\end{tabular}

Źródło: opracowanie własne.

Kobiety są sprowadzone do roli pomocników, uzupełniają mężczyznę o cechy, które są mu, według PB, zupełnie niepotrzebne. Nie powinny się skrywać ze swoją seksualnością, jednakże powinny zachować wierność i nie być rozpustne. Uzależniają siebie od opinii innych. Z natury unikają konfrontacji: „Większość kobiet, które znam, są zbyt zainteresowane wpasowywaniem się w obecne trendy i potrzebą akceptacji społecznej. Z natury unikają konfrontacji i nie chcą być postrzegane jako obalające obowiązujący system".

Porząna dziewczyna ma długie włosy i konserwatywne poglądy. Te z krótkimi włosami zazwyczaj są szalone i nie nadają się do niczego innego poza seksem. Dla mężczyzn najbardziej atrakcyjna kobieta ma duże cycki $i$ dupę: „całowanie się z dziewczyną, która ma krótkie włosy. Na początku wszystko wydaje się ok, ale kiedy złapiesz ją za tył głowy, masz wrażenie, że całujesz się z dziwnym chłopcem".

W dyskursie PB dziewczyny (młode) są kojarzone z seksem i podrywem, żony się bierze, a kobiety szanuje. Są to cele do zdobycia. Często są sprowadzane tylko do roli cipki i pięknego stworzenia. Celem jej życia powinno być urodzenie dziecka, a następ- 
nie opiekowanie się domem. Są opisywane jako selektory matki natury, wybierające geny nadające się do przedłużenia gatunku (czyli samców alfa).

Komunikacja PB wokół leksemu żona opiera się na obowiązkach mężczyzny wobec niej. Powinna być kochana i zadowalana w łóżku. Cechy nadawane żonie nie różnią się od cech kobiety oprócz tego, że występuje ona także w negatywnych kontekstach. W przeciwieństwie do kobiety lub dziewczyny, żona zawsze znajdzie powód do ponarzekania. Kolejna rola, w jaką wciela się kobieta, to rola matki. Jest to jej przeznaczenie, kobieta nie powinna niczego przedkładać nad tę rolę. Przybierając ją, zyskuje powszechny szacunek i jest ciepło opisywana. Najsilniejsza cecha z nią utożsamiana to opiekuńczość.

Nie wszystkie kobiety są dobre. W swojej komunikacji PB opisują także kobiety upadłe, czyli feministki. Te, które korzystają z rządowych programów aborcyjnych, są nazywane rozwiązlymi kurwami. Jeżeli wyznają lewicowe poglądy, to znaczy, że mają wyprane mózgi. Feministki uważają, że wszyscy mężczyźni to gwałciciele, i to przez nie konserwatywni mężczyźni zmieniają swoje poglądy polityczne. Łatwiej jest złożyć im fałszywe oskarżenia w sprawach sądowych przeciwko mężczyznom. Opisane powyżej kobiety często były w przeszłości skrzywdzone. PB nazywają je szalonymi cipami, które nadają się tylko do uprawiania z nimi seksu. Kobiety z lewicowymi poglądami nie zasługują jednak na dobre traktowanie i seks z nimi nigdy nie powinien być dla nich zbyt dobry - mężczyzna nie powinien dać w nim z siebie wszystkiego. Kobiety nie nadają się także do wojska, ponieważ nie ma w nim miejsca na słabość.

\section{Podsumowanie}

Hipoteza badawcza zakładała, że „konstrukt męskości wynikający z komunikacji Proud Boys różni się od wzoru męskości typowego dla skrajnie prawicowych organizacji”. Przeprowadzone badanie zweryfikowało ją negatywnie. Obraz męskości wynikający z komunikacji Proud Boys nie wyróżnia się znacząco na tle komunikacji skrajnej prawicy. Według nich mężczyzna powinien być kochającym rodzinnym człowiekiem, patriotą gotowym zginąć za ojczyznę oraz czułym kochankiem. Istotna jest rola sportu w życiu mężczyzny. Aktywność fizyczna ma przygotować go na życiowe trudy, wyrobić w nim odpowiednią siłę fizyczną oraz zahartować psychicznie, stworzyć twardego człowieka, który nadawałby się także do uczestnictwa w bójkach ulicznych.

Wyniki badań dyskredytują twierdzenia $\mathrm{PB}$ o ich rzekomym pozytywnym stosunku wobec homoseksualistów. Stosowanie określeń gej lub gejowski jako inwektyw wobec niemęskich osób zaprzecza oświadczeniom o liberalnym spojrzeniu Proud Boys na kwestie orientacji seksualnej.

Masturbacja i pornografia nie znajdują wiele miejsca w dyskursie PB. Są wykorzystywane w celu przedstawienia konceptu niemęskości, jednak skala tego zastosowania nie współgra $\mathrm{z}$ ekspozycją tematu w materiałach promocyjnych grupy. 
Rola kobiet także nie różni się od utrwalonych stereotypów. Kobiety powinny zajmować się domem, rodzić dzieci i dbać o siebie, żeby podobać się mężowi. Kariera zawodowa jest niewskazana, podobnie jak decyzyjność i wzięcie odpowiedzialności za swoje życie. Kobieta powinna być jednocześnie skromna, czuła i opiekuńcza, ale także potrafić dobrze się bawić i eksponować swoją seksualność.

Obraz męskości proponowany przez Proud Boys jest atrakcyjny dla młodych, pogrążonych w kryzysie tożsamości mężczyzn. Rozwiązaniem ich problemów wydaje się bezpieczny świat, gdzie cel życia jest jasno określony, kobiety nie stanowią zagrożenia, a wzór męskości sprowadza się do kilku tradycyjnych cech. W związku z tym należałoby dokładniej zbadać, w jaki sposób Proud Boys rekrutują nowych członków. Poznać ich strategię i retorykę w bezpośrednich kontaktach z potencjalnie zainteresowanymi osobami. Badanie to należałoby także rozszerzyć na inne grupy, organizacje i ruchy, które zazwyczaj są większe i bardziej radykalne, na przykład MGTOW (Man Going Their Own Way), Inceli (Involuntary Celibate), czy Pick Up Artists (Artystów podrywu). Potrzebna jest odpowiedź na pytanie, w jaki sposób ruchy promęskie i skrajnie prawicowe zagospodarowują potrzebę znalezienia tożsamości i dlaczego są one tak skuteczne. Ciekawe byłoby też badanie porównawcze obrazu męskości proponowanego przez lewicowe ruchy, które mogłoby zdiagnozować przyczyny ich porażki na tym polu. Czy jej źródło leży w założeniach dotyczących męskości, sposobie jej komunikowania, braku obecności w odpowiednich miejscach, czy może niezrozumieniu powodów frustracji młodych mężczyzn?

\section{Bibliografia}

Baker P., Using Corpora in Discourse Analysis, London-New York 2006.

Graff A., Manosfera, czyli bunt upokorzonych samców, „Czas Kultury” 2019, nr 1, s. 15-20.

Hawley G., The Alt-Right, New York 2019.

Hawley G., Making Sense of the Alt-Right, New York 2017.

Jane E., Misogyny Online, Los Angeles 2016.

Kamasa V., Techniki językoznawstwa korpusowego wykorzystywane w krytycznej analizie dyskursu. Przegląd, „Przegląd Socjologii Jakościowej” 10, 2014, nr 2, s. 100-117.

Kennedy G., An Introduction to Corpus Linguistics, London-New York 1998.

Kimmel M., Angry White Men. American Masculinity at the End of an Era, New York 2013.

Main T., The Rise of Alt-Right, Washington, D.C. 2018.

Melosik Z., Kryzys męskości w kulturze współczesnej, Kraków 2006.

Nagle A., Kill All Normies, Washington 2017.

Pawlikowska A., Zastosowanie metod językoznawstwa korpusowego i lingwistyki kwantytatywnej w analizie dyskursu, „Oblicza Komunikacji” 5, 2012, s. 111-125.

Rykiel Z., Klaunokracja 2.0 i bolesny koniec patriarchatu na semiperyferiach, „Przestrzeń Społeczna” 2016, nr 2, s. 7-32.

Sinclair J., Reading Concordances. An Introduction, London 2003.

Stubbs M., Words and Phrases. Corpus Sudies of Lexical Semantics, Oxford 2002. 
Śledź P., Alt-Right - geneza i próba zdefiniowania zjawiska, [w:] Zmierzch demokracji liberalnej?, red. K.A. Wojtaszczyk, P. Stawarz, J. Wiśniewska-Grzelak, Warszawa 2018, s. 163-174.

Wierzbicka A., Słowa klucze. Różne języki - różne kultury, przeł. I. Duraj-Nowosielska, Warszawa 2007. Zimbardo P., Duncan N., The Demise of Guys. Why Boys Are Struggling and What Can We Do About It, New York 2012.

\title{
Źródła internetowe
}

Kelly A., The alt-right: Reactionary rehabilitation for white masculinity, Eurozine, 15.09.2017, https://www. eurozine.com/the-alt-right-reactionary-rehabilitation-for-white-masculinity/ (dostęp: 8.06.2019).

Lyons M., Ctrl-Alt-Delete: The origins and ideology of the Alternative Right, Political Research Associates, 20.01.2017, https://www.politicalresearch.org/2017/01/20/ctrl-alt-delete-report-on-the-alternative-right (dostęp: 8.06.2019).

Pacewicz K., Młodzi mężczyźni są prawicowi i samotni, a młode kobiety liberalne i w związkach [SONDAŻ], Wyborcza.pl, 27.04.2019, http://wyborcza.pl/magazyn/7,124059,24700696,mlodzi-wypisali-sie-z-politycznej-wojny-starszych-maja.html (dostęp: 6.09.2019).

Zimmermann S., Ryan L., Duriesmith D., Recognizing the Violent Extremist Ideology of 'Incels', Women in International Security, 30.09.2018, https://www.wiisglobal.org/publication/recognizing-theviolent-extremist-ideology-of-incels/ (dostęp: 8.06.2019).

\section{The image of masculinity in the communication of extreme right-wing organization Proud Boys}

\begin{abstract}
Summary
The article tells how the Proud Boys group, which is part of the Alt-Right movement, constructs masculinity. I examined the corpus comprising articles published on the official Proud Boys website. The methods used to conduct the research were characteristic of corpus linguistics. The paper takes into account how the Proud Boys group presents a "real" man, specifies his characteristics, checks if the image is coherent with the group's promotional materials and also describes the negative stereotypes of a "beta male", which is used to differentiate the desired patterns. The research further reviews the role of pornography in the organization's communication and the image of women and womanhood resulting from its communication.
\end{abstract}

Keywords: masculinity, corpus linguistics, alt-right, proud boys, corpus study 